\title{
a revolução dos vapores na navegação marítima ${ }^{\star}$
}

\section{the revolution of vapors in maritime navigation}

\author{
Thiago Vinícius Mantuano da Fonseca $\star \star$ \\ Instituto de História, Universidade Federal Fluminense, Niterói, Rio de Janeiro, Brasil
}

\begin{abstract}
RESUMo
O presente artigo pretende demonstrar como o transporte marítimo transoceânico foi revolucionado durante o segundo ciclo de industrialização, no contexto de ascensão do capitalismo monopolista. Neste texto, pretendemos discutir a existência da Segunda Revolução Industrial. Trabalhando com as críticas às interpretações que a afirmam, vincularemos o processo realmente existente à exploração de novas potencialidades técnico-científicas pelo imperialismo. $\mathrm{O}$ objetivo central deste trabalho é exatamente demonstrar as grandes transformações (qualitativas e quantitativas) na navegação transoceânica com a introdução de outra base material e técnica, além de novas tecnologias; entretanto, intentaremos correlacionar essas mudanças a um novo paradigma econômico-social marcado pela mundialização do capitalismo.
\end{abstract}

Palavras-chave: Navegação. Segunda Revolução Industrial. Imperialismo.

\begin{abstract}
The present article intends to demonstrate how the transoceanic maritime transport was revolutionized during the second cycle of industrialization in the context of the rise of monopoly capitalism. In this text, we intend to discuss the existence of the Second Industrial Revolution. Working with criticisms of the interpretations that affirm it, we will link the really existing process to the exploration of new technical-scientific potential by imperialism. The main objective of this work is to demonstrate the great transformations (qualitative and quantitative) in the transoceanic navigation with the introduction of another material and technical base, as well as new technologies; however, we will try to correlate these changes with a new economic-social paradigm marked by the globalization of capitalism.
\end{abstract}

Keywords: Navigation. Second Industrial Revolution. Imperialism.

* Uma versão preliminar deste artigo foi apresentada no XII CONGRESSO BRASILEIRO DE HISTÓRIA ECONÔMICA, sendo elaborado em homenagem aos cem anos da primeira edição de O imperialismo: fase superior do capitalismo (1917). Este artigo faz parte do trabalho financiado pela CAPES-PROEX (2015-2017).

Submetido: 26 de fevereiro de 2018; aceito: 11 de outubro de 2018.

$\star \star$ Doutorando e mestre em História Social pela Universidade Federal Fluminense. E-mail: thiago_mantuano@id.uff.br 


\section{A chamada Segunda Revolução Industrial}

A tradição crítica da historiografia costumou-se, a partir principalmente de Hobsbawm, a problematizar a existência de uma Segunda Revolução Industrial. Lembramos que Marx, Engels e Lenin notam uma nova fase da industrialização na segunda metade do século XIX, mas apenas Lenin se atém ao seu caráter transformador, entretanto sem entrar no mérito se havia ou não uma nova Revolução Industrial. A historiografia crítica tem pontuado os limites desta, mas não conseguimos identificar em nenhum dos autores estudados o que nos parece o melhor sentido do conceito. Autores como Dobb, Sweezy, Baran, Kemp e Beaud contestam o sentido da chamada Segunda Revolução Industrial sem refutá-la de pronto.

De fato, cremos que houve uma segunda fase da Revolução Industrial no pós-1850, mas estamos longe do viés liberal que atribui a esta (com ênfase na "revolução" técnico-científica) as mudanças que ocorreram no padrão de acumulação capitalista do fim de século. Parece-nos o contrário! As potencialidades técnico-científicas só puderam ser plenamente executadas e aplicadas em um novo ciclo de industrialização, pois este era impulsionado por uma nova fase do capitalismo.

A Segunda Revolução Industrial que tratamos não reside apenas na implementação de novas fontes e formas de energia, como o petróleo e a eletricidade; ou de novos materiais, como o aço; ou no grande aprimoramento de inventos do século XVIII, como a turbina a vapor; nem mesmo reside exclusivamente na industrialização de outros países, como Alemanha e Estados Unidos. A essência da chamada Segunda Revolução Industrial está na mudança do caráter do capitalismo: nesse momento, monopolista e imperialista.

O capitalismo monopolista criou uma nova fase de desenvolvimento das forças produtivas. Certamente esse desenvolvimento não está desassociado da longa trajetória de avanços desde as décadas finais do século XVIII, é um processo intrínseco ao desenrolar do capitalismo como modo de produção, mas ainda assim há uma nova fase. Assim como a fase monopolista, é o resultado tendencial do desenvolvimento capitalista nos primórdios como capitalismo concorrencial; a Segunda Revolução Industrial é consequência tendencial das características mais básicas da primeira. Os dois processos estão em relação dialética e não podem ser entendidos de forma desassociada. 
É verdade que as inovações técnicas e tecnológicas foram importantes fatores para concentração de capitais, pois que agigantavam as proporções produtivas, as plantas fabris, as escalas de mercadorias e necessidades de capitais. Entretanto, decisivamente, a concentração de capitais liberou forças que fizeram o capital avançar em suas capacidades de transformação de forma renovada e com repercussões tão importantes quanto das últimas décadas do século XVIII.

As mudanças tecnológicas e socioeconômicas, ocorridas desde a Revolução Industrial e a expansão do capitalismo, implicaram transformações profundas na navegação. A invenção e generalização do vapor nas embarcações, dos cascos de ferro, do carvão mineral de pedra do tipo coke e do guindaste de bordo foram resultados de um movimento duplo: a demanda por um fluxo de trocas quantitativamente e qualitativamente diferentes com a periferia do sistema, a construção de embarcações maiores em termos de espaço e autonomia, mais seguras e regulares não apenas subsidiaram o capitalismo de tipo imperialista, como foram desenvolvidas (especialmente na sua forma transatlântica) por conta dele.

Partindo do nosso enfoque, consideramos que, se existe uma Segunda Revolução Industrial, ela só teve condições de florescer graças à nova fase do capitalismo, agora monopolístico e em um processo de fusão entre o capital bancário e o produtivo. Nessa segunda fase, buscava-se novas áreas de investimento: investia-se na indústria pesada, pois os bens de capitais eram necessários para as novas frações do globo em industrialização; investia-se em indústria química, porque a massificação dos bens de consumo exigia novas e variadas mercadorias (como o automóvel ou a bicicleta); investia-se na eletricidade para dar maior liberdade aos capitalistas de escolher onde construir suas fábricas; investia-se na maior potência e capacidade de antigos inventos para efetivar as mercadorias em várias regiões do globo, e nesse sentido os transportes foram grandemente afetados. Todo esse encadeamento se deu a partir da Grande Depressão (1873-1896) e do Imperialismo Capitalista, sem esse revés e sua solução, dificilmente o capitalismo teria motivação e fôlego para uma nova e impressionante aceleração no desenvolvimento das forças produtivas, a chamada Segunda Revolução Industrial.

Embora não tratem nesses termos, da chamada Segunda Revolução Industrial, Lenin, Bukharin e Hilferding registram o processo no sentido que nos parece mais justo. Lenin baseia sua avaliação no binômio in- 
dustrialização-concentração: "O enorme desenvolvimento da indústria e o processo notavelmente rápido de concentração da produção, em empresas cada vez maiores, constituem uma das características mais marcantes do capitalismo" (Lenin, 2013, p. 118). Parece-nos que o revolucionário russo se refere exatamente ao processo que ficou conhecido como Segunda Revolução Industrial. Entretanto, sem sopesarmos o fator da concentração de capitais nos monopólios, o entendimento sobre o aceleramento e expansão da industrialização para o imperialismo é incompleto (Lenin, 2013, p. 216).

Da mesma forma, Bukharin assevera que "a incrível rapidez da expansão da economia mundial, nas últimas décadas, foi provocada pelo extraordinário crescimento das forças produtivas do capitalismo, o que podemos mostrar pelo progresso técnico" (Bukharin, 1984, p. 25). A importância desse salto qualitativo no processo produtivo está posta pelo autor: "Em momento algum, a justaposição da ciência e da técnica conheceu triunfos tão retumbantes como hoje. A racionalização da produção tomou a forma de íntima colaboração entre as ciências abstratas e as realizações práticas" (Bukharin, 1984, p. 25). Mesmo que o autor não trate em nossos termos, é claro em atribuir semelhante sentido ao processo que chamamos de Segundo Revolução Industrial:

Assim, o desenvolvimento do processo da economia mundial, que repousa sobre a expansão das forças produtivas, conduz não somente ao estreitamento das relações de produção entre os diferentes países, à multiplicação e ao fortalecimento das relações capitalistas, como também à geração de novas formações econômicas, desconhecidas nas faces precedentes do sistema capitalista. (Bukharin, 1984, p. 30)

Enxergando pela ótica da criação do sistema financeiro, Hilferding lembra que a chamada Segunda Revolução Industrial fazia parte de um processo em que era necessário fazer exportar um verdadeiro "pacote" para boa parte do globo terrestre, por parte das potências capitalistas centrais. Através das revolucionárias técnicas e tecnologias, além dos meios de financiamento e dos recursos humanos para sua implementação, o capitalismo passava a impor (ou, ao menos, ter os seus interesses presentes) mundialmente seus ritmos e magnitudes produtivas. 
O desenvolvimento capitalista não se deu de modo autóctone em cada país isoladamente; pelo contrário, com o capital foram simultaneamente importadas produção capitalista e relações de exploração, e isso sempre no grau alcançado no país mais avançado. Assim como hoje, uma indústria recém-criada não se desenvolve a partir de princípios e técnicas artesanais para chegar a ser uma gigantesca empresa moderna, mas é fundada de antemão como empresa altamente capitalista, assim o capital, hoje, também é importado por um novo país com o respectivo grau de perfeição e desenvolve por seu efeito revolucionário com ímpeto muito maior e em prazo muito mais curto do que exigiu, por exemplo, o desenvolvimento capitalista da Inglaterra. (Hilferding, 1985, p. 303)

O sistema se mundializava como relação social de produção capitalista, essa era a parte mais proeminente do "pacote" produzido na Europa e efetivado em todo o mundo. Esse processo tem nome e sobrenome: Imperialismo Capitalista.

\section{O imperialismo: a Segunda Revolução Industrial potenciada pelos monopólios}

O curto-circuito na acepção a respeito dos processos de Segunda Revolução Industrial e Imperialismo Capitalista se deu, exatamente, porque a associação entre o novo fôlego para o avanço das forças produtivas e a imposição do capitalismo como relação social de produção, em novas áreas do globo, não foi sistematizada de forma conjugada. No geral, os estudiosos do Imperialismo Capitalista secundarizaram os avanços materiais, técnicos e tecnológicos criados na segunda metade do século XIX, enquanto os estudiosos da Segunda Revolução Industrial relegaram ao segundo plano as transformações sociais e econômicas operadas internamente ao sistema capitalista, especialmente a mudança do caráter concorrencial para o monopolista. As perguntas que nos fazemos são: Qual a possibilidade dos dois processos serem coexistentes, conexos e se retroalimentarem? E, mais, qual dos dois fatores ordena a relação?

Basicamente, a segunda fase do capitalismo é identificada pelas "Sociedades Anônimas Gigantes” (Sweezy; Baran, 1966), os monopólios aparecem em um processo em que o capital bancário e o industrial 
rapidamente estão se amalgamando, disso surge o capital financeiro; esse fenômeno dataria mais ou menos da passagem do século, quando os processos industriais de grande escala se tornavam possíveis com o advento da Segunda Revolução Industrial. Percebam que a concentração de capitais e a revolução técnico-científica, ocorridas na segunda metade do século XIX, se retroalimentam. Cremos que, sem a gigante capacidade de inversão possibilitada pelo capital financeiro, todas as potencialidades exploradas na Segunda Revolução Industrial não teriam se efetivado.

Gráfico 1 - Capitais investidos no exterior pelas potências europeias (em bilhões de francos)

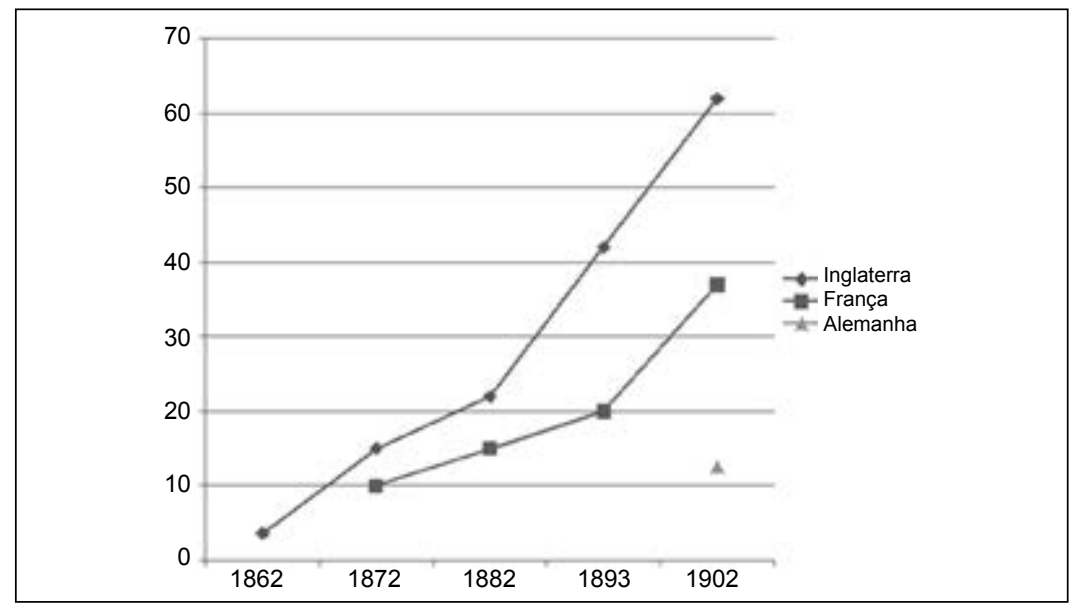

Fonte: Lenin (2013, p. 182).

Nas palavras de Lenin, “o que caracterizava o velho capitalismo, onde reinava plenamente a livre concorrência, era a exportação de mercadorias. O que caracteriza o capitalismo moderno, no qual impera o monopólio, é a exportação de capital" (Lenin, 2013, p. 180), como demonstrado pelos números que nos fornece o próprio autor.

A revolução no modo de produção na indústria e na agricultura provocou também uma revolução nos meios de comunicação e transporte, assim como a concentração dos capitais também pode ser reconhecida de pronto nesse setor. Os meios de transporte e de comunicação, legados pelo período manufatureiro, logo se transformaram em insuportáveis 
estorvos para a grande indústria monopolista, com sua velocidade febril de produção, sua escala maciça e crescente, seu constante deslocamento e concentração de capital, sua forte centralização das unidades produtivas e do seu conjunto cada vez maior de trabalhadores, além das fortalecidas conexões com o mercado mundial. Como registrado por Marx,

assim, abstraindo da construção de veleiros, que foi inteiramente revolucionada, o sistema de comunicação e transporte foi gradualmente ajustado ao modo de produção da grande indústria por meio de um sistema de navios fluviais, transatlânticos a vapor, ferrovias e telégrafos. (Marx, 1988, p. 440)

Marx aponta claramente para os enormes esforços feitos, em meados do século XIX, na construção de uma moderna e industrial rede de comunicações e transportes como um dos fatores fundamentais para constituição da indústria de bens de capitais. "Construir máquinas com máquinas" era o novo objetivo dos capitalistas, que já vislumbravam a extrapolação dos seus investimentos para outros rentáveis setores e para a disputa de novas formações sociais.

Nessa esteira, as antigas relações sociais desaparecem, o isolamento de povos na tranquilidade de sua vida campesina é interrompido para todo sempre, as novas nações se veem arrastadas pelo redemoinho capitalista e não têm forças de reação, por via de regra se entregam apaixonadamente pela "modernidade" que esse modo de produção proporciona.

Com o crescimento da urbanização, e a crescente predominância da população urbana, amontoada em grandes centros pela produção capitalista, a cidade acumula a força vital histórica da sociedade capitalista e desvirtua a estreita relação entre o homem e a terra. Esse movimento destrói tanto a saúde física dos trabalhadores urbanos como a saúde mental dos trabalhadores rurais.

Mesmo com todos esses indícios, alguns autores se mostram impassíveis e não consideram essas mudanças qualitativamente relevantes. Para Jean-Pierre Rioux, por exemplo, a Segunda Revolução Industrial não é nada mais do que a continuação da primeira. Assim, não faria tanto sentido chamá-la dessa forma, pois esse processo seria o prosseguimento natural da acumulação capitalista:

As inovações técnicas do fim do século - esta "segunda revolução industrial" de certos autores - e as inovações industriais não modificaram 
fundamentalmente os antigos equilíbrios: permitiram simplesmente às economias dominantes fazer crescer seu poder e criar novos focos de industrialização no mundo. Na era do petróleo, da eletricidade e da química, novos setores de crescimento puderam revitalizar as velhas produções industriais ultrapassadas, mas não modificaram fundamentalmente o equilíbrio anterior. (Rioux, 1975, p. 83)

Outros autores, como David Landes (1994), reconhecem o imperialismo como parte desse processo de novo revolucionamento das forças produtivas, entretanto veem o imperialismo como "efeito inevitável" das demandas criadas pelo que chama de Segunda Revolução Industrial. Landes se distancia de nossa interpretação dos fatos, que é exatamente inversa em sua ordem: a Segunda Revolução Industrial surge exatamente das demandas criadas por uma nova fase característica do capitalismo.

A invenção social, e não a técnica ou tecnológica, fora a fonte intelectual da Primeira Revolução Industrial. O século XIX, especialmente em sua segunda metade, no que convencionamos chamar de Segunda Revolução Industrial, mudou essa lógica: a ciência e a indução de novas soluções produtivas tomaram o manche da inovação na Europa.

A produção mecanizada se generalizou. Os capitalistas passaram então a analisar e dividir o processo produtivo em fases constitutivas, assim resolveram os problemas por meio da aplicação da mecânica, da química, da eletricidade, da engenharia etc. Logo a maquinaria se impôs nas manufaturas, com isso, a divisão do trabalho manufatureira, que tem origem em antigas relações sociais, é dissolvida e dá lugar a uma tendência inovadora constante. O trabalho passa a requerer novas qualificações, cada vez mais simples e necessariamente adaptáveis à máquina. Nas palavras de Marx,

contrariamente ao período da manufatura, agora o plano da divisão do trabalho se baseia, sempre que possível, na utilização do trabalho feminino, do trabalho de crianças de todas as idades, de trabalhadores não qualificados, em suma, do "cheap labour", o "trabalho barato", como o inglês o denomina de modo tão característico. (Marx, 1988, p. 524)

Entretanto, é necessário ressalvar que a segmentação não traz consigo uma especialização a priori, a divisão técnica do trabalho não está em causa como especificamente capitalista; no caso dos trabalhadores ma- 
rítimos e portuários, mesmo após a revolução dos vapores marítimos, tinham alguma noção global do processo de produção. A evolução dessa segmentação foi estratificada, com efeito houve a diminuição do número de atividades que um trabalhador realiza ao longo da vida na cadeia produtiva. Como deixa claro Caruso,

en torno a la organización y materialidad del trabajo a bordo, estas fueron alteradas por sucesivos y múltiples cambios e innovaciones tecnológicas. Con ellas, se transformaram las condiciones de trabajo en el barco, se crearon nuevas actividades, calificaciones y secciones, y se suprimieron otras. Dichas innovaciones respondían en principio a la dinámica competitiva propria del capitalismo. (Caruso, 2016, p. 13)

A tensão do capital foi neste sentido: lentamente vai restringindo a possibilidade de um trabalhador participar de várias áreas da produção ao longo da vida, ao mesmo passo que multiplicava a quantidade delas, segmentando a produção. Entretanto, ainda durante o século XIX, sem dominar os ofícios, muito dependente dos conhecimentos e da força fisica dos trabalhadores a bordo e nos portos, a força do capital não conseguiu especializá-los por completo e padronizar os seus procedimentos, por mais que esse processo tenha andado mais aceleradamente nas embarcações que nos portos.

A Segunda Revolução Industrial estreou o desenvolvimento de mecanismos complexos, especialmente algumas máquinas que têm atributos da mente humana, como a memória, algum julgamento elementar, a precisão e o poder de calcular (Mason, 1993). Enrique Dussel nos traz uma importante abordagem crítica do papel da ciência durante essa nova fase do capitalismo: "Esta trasnacionalización del capital productivo y financeiro es un hecho reciente y exije un nuevo desarrollo teórico, donde nuevamente la tecnología vuelve a jugar una función determinante, como revolución científico-tecnológica" (Dussel, 1984, p. 75). A revolução científico-tecnológica aparece, para o autor, como as pernas necessárias para a efetivação da maior vocação do capitalismo como modo de produção: ser universal.

A questão é que a crescente complexidade dos processos produtivos, no século XIX, ao mesmo tempo em que incrementou a objetivação do trabalho e implicou a independência da perícia humana em certos 
processos de trabalho, exponenciou a necessidade dessa mesma perícia $\mathrm{e}$, constantemente, da força humana em outros ofícios. Isso ficava muito claro quando as embarcações ancoravam nas baías dos principais portos atlânticos.

A indústria naval, por exemplo, experimentou um processo contínuo de desenvolvimento e queda dos seus custos de produção, por conta, exatamente, da nova revolução tecnológica:

Hasta la Revolución industrial de los ferrocarrile y barcos de vapor (que abrieron nuevas fuentes de aprovisionamento baratas como el Medio Oeste americano), las aplicaciones individuales de maquinaria a la agricultura (como el molino azucarero movido por vapor), y una creciente demanda de materias primas no agrícolas, tales como productos mineros y petrolíferos, transformaron el sector primario, y por tanto los índices del comercio tendieron a moverse contra los productos industriales de rápido abaratamiento. (Hobsbawm, 1982, p. 137)

Durante esse processo, o contingente da marinharia, para operar naves cada vez maiores, mais velozes e mais complexas, diminuiu a olhos vistos. $\mathrm{O}$ intento dos armadores era simplificar tarefas e aumentar performance, diminuir a tripulação e extrair maior fatia dos ganhos de produtividade no trabalho. O insuspeitamente liberal Alfred Marshall retrata esse quadro com perfeição: "O custo de um navio a vapor equivale, talvez, ao trabalho de dez anos ou mais de quem trabalha nele" (Marshall, 1996, p. 283).

$\mathrm{Na}$ "Era de Ouro" do capitalismo oitocentista (a saber: entre 1848 e 1873, os anos do boom ferroviário), todo o continente europeu foi dotado de novas formas de comunicação e transporte, a produção estava mais integrada e o seu processo de concentração passou a ser gestado. Como nota Hobson:

Não é, entretanto, na manufatura e sim na indústria do transporte que iremos encontrar os resultados mais expressivos da influência concentradora da maquinaria. A substituição da carroça e da diligência pela estrada de ferro, do barco a vela pelo navio a vapor, evidencia o maior avanço do capitalismo moderno. (Hobson, 1983, p. 91)

Durante os anos de Depressão, a saturação das oportunidades de in- 
vestimento/realização na velha Europa e a necessidade de integrar vastas áreas do globo, fornecedoras de insumos e matérias-primas, consubstanciaram nos transportes e comunicações os setores-chave para dar conta dos novos desafios do capitalismo. A saída da crise foi iluminada pelo imperialismo e transportada via trilhos de ferro, cabos telegráficos e navios a vapor por empresas monopolísticas. Hilferding faz relevante arrazoado do processo:

A revolução no sistema de transportes marcou época na história da exportação de capital. As estradas de ferro e a navegação a vapor tem em si uma importância colossal para o capitalismo, devido à redução do tempo de circulação. Com isso, primeiro libera-se o capital de circulação e, depois, eleva-se a taxa de lucro. $\mathrm{O}$ barateamento da matéria-prima reduz o preço de custo e amplia o consumo. Logo, as estradas de ferro e o navio a vapor criam aqueles grandes espaços econômicos que possibilitam os gigantescos estabelecimentos modernos, com sua produção em massa. [...] Contudo, mais importante ainda foi o fato de a exportação de capital ter se tornado agora necessária em proporções maiores para a construção dessas ferrovias, construídas quase exclusivamente com capital europeu, nomeadamente com o inglês. (Hilferding, 1985, p. 303)

Nesse momento, o consumo mais necessário para reprodução sistêmica era o de capitais, investir se tornava cada vez mais imperioso para realizar as potencialidades técnico-científicas então criadas. Como assevera Brown:

A necessidade de encontrar novos mercados para a produção de bens de capital é um problema fundamental do capitalismo. Em certo sentido, o imperialismo consistiu em reter as indústrias de bens de capital na Grã-Bretanha e outros países industriais avançados e permitir que somente indústrias de bens de consumo se desenvolvessem em outros países numa divisão internacional do trabalho artificial, causada, em grande parte, pelo desequilíbrio interno entre a produção de bens de capital e bens de consumo. (Brown, 1978, p. 55)

Disso, concluímos que os mercados externos novamente voltaram ao centro das atenções capitalistas. Não que tivessem se esquecido destes, mas o grande crescimento populacional, sua consequente expansão urbana e a implantação da moderna infraestrutura na velha Europa já 
mostravam seus limites, enquanto a produção crescia em ordem totalmente desproporcional ao mercado interno.

Tabela 1 - Investimento externo como parte da formação líquida de capital

\begin{tabular}{c|c|c|c}
\hline \multicolumn{2}{|c}{ ReINo UnIDO } & \multicolumn{2}{c}{ AlemANHA } \\
\hline $1855-1864$ & $29,1 \%$ & $1851-1861$ & $2,2 \%$ \\
\hline $1865-1874$ & $40,1 \%$ & $1861-1871$ & $12,9 \%$ \\
\hline $1875-1884$ & $28,9 \%$ & $1871-1881$ & $14,1 \%$ \\
\hline $1885-1894$ & $51,2 \%$ & $1881-1891$ & $19,9 \%$ \\
\hline $1895-1904$ & $20,7 \%$ & $1891-1901$ & $9,7 \%$ \\
\hline
\end{tabular}

Fonte: Landes (1994, p. 342).

A diminuição das distâncias espaço-temporais é uma consequência inequívoca dessa segunda fase da industrialização, agora mundial, embora desigual e combinada. A Divisão Internacional do Trabalho que se estabeleceu impingia às nações a busca das suas vantagens comparativas e, com isso, todas as economias nacionais eram reordenadas. Assim, o Brasil, como de resto a América Latina, moldou e aperfeiçoou sua estrutura socioeconômica para o modelo agroexportador.

Segundo Landes, o século XIX foi um "ponto fora da curva dos preços” (Landes, 1994, p. 243), ou seja, diferentemente da tendência natural de depreciação e inflação, que podem ocorrer de forma mais amena ou abrupta, houve uma deflação crônica pontuada por alguns momentos de altas nos preços. Esse fenômeno está amplamente ligado ao desenvolvimento generalizado e cientificamente deliberado das forças produtivas, especialmente durante a Segunda Revolução Industrial, quando suas implicações se radicalizaram na vida social e na política global.

Nos mares não foi diferente, todo esse revolucionamento das forças produtivas diminuiu grandemente o custo dos fretes; apesar do grande investimento, o transporte marítimo viu seus custos caírem para cerca de um sexto dos índices registados no início do século, enquanto o transporte terrestre tivera um barateamento de cerca de 90\% (Suárez Bosa, 2013).

No século XIX, o ritmo do desenvolvimento das forças produtivas, desde a infraestrutura da indústria ao volume de produção, extensão e variedade do comércio, mostrou-se inteiramente frenético. A julgar pelos padrões feudais, essa mudança foi tão anormal a ponto de dar novo sentido à vida humana. Disso, conclui Maurice Dobb: “É evidente - mais 
do que em qualquer outro período histórico - que a interpretação do mundo econômico do século XIX tem de ser essencialmente uma interpretação de sua transformação e movimento" (Dobb, 1983, 184).

O século XIX foi marcado pela transformação técnica, que incrementava produtividade do trabalho na mesma proporção que expandia o exército industrial de reserva. Um emaranhado conjunto de fatores ampliava simultaneamente as oportunidades e áreas de investimento, além do próprio crédito. $\mathrm{O}$ mercado dos bens de consumo fora ampliado e diversificado de forma sem precedente, os homens viviam em um mundo cada vez menos seu e cada vez mais das mercadorias.

A Primeira Revolução Industrial tem liderança inconteste da Inglaterra, mas é durante a Segunda Revolução Industrial que o Império britânico perde a hegemonia indubitável do mundo capitalista. Antes, como parte desse processo, a Inglaterra se beneficiou fornecendo bens de capital, técnicas, saber científico, recursos humanos, capitais e tudo o mais necessário para o arranque industrial dos seus principais rivais nesse novo ciclo, a saber: Estados Unidos e Alemanha.

A principal característica dessa nova industrialização é a tendência ao monopólio ou oligopólio, inegavelmente na indústria pesada, principalmente em setores estritamente relacionados com as encomendas governamentais, como o de armamentos, mas também em atividades que geram e distribuem novas formas revolucionárias de energia, como o petróleo e a eletricidade, e principalmente nos transportes de longa distância.

Tabela 2 - Balanço dos pagamentos correntes da Grã-Bretanha (média anual em milhões de libras)

\begin{tabular}{|c|c|c|c|c|c|c|}
\hline & $\begin{array}{l}\text { BALANÇA } \\
\text { COMERCIAL }\end{array}$ & $\begin{array}{l}\text { IMIGRANTES, } \\
\text { TURISTAS E } \\
\text { GOVERNOS }\end{array}$ & $\begin{array}{c}\text { TRANSPORTES } \\
\text { MARÍTIMOS }\end{array}$ & $\begin{array}{l}\text { LUCROS, } \\
\text { JUROS E } \\
\text { DIVIDENDOS }\end{array}$ & $\begin{array}{c}\text { SEGUROS, } \\
\text { CORRETAGEM } \\
\text { E COMISSÕES }\end{array}$ & TOtAL \\
\hline $1866-1870$ & -65 & -9 & +45 & +57 & +13 & +41 \\
\hline $1876-1880$ & -124 & -9 & +54 & +88 & +16 & +25 \\
\hline $1896-1900$ & -159 & -11 & +62 & +132 & +16 & +40 \\
\hline
\end{tabular}

Fonte: Beaud (1989, p. 163-202).

Ao passo que os colossos, trustes e cartéis, alemães e americanos prosperavam, o Império ainda conservava importante posição financeira e no comércio internacional: "De fato, à medida que a concorrência 
estrangeira ia prejudicando a indústria britânica, a City de Londres e a marinha mercante britânica iam se tornando mais centrais que nunca para a economia mundial" (Hobsbawm, 1988, p. 71).

Tom Kemp considera que a perda de hegemonia inglesa era relativa, o mundo pode ter se tornado multipolar, mas era em Londres que se achavam capitais e era através da Marinha Mercante inglesa que boa parte deles se efetivava: "Sin embargo, su historia de liderazgo económico y su ininterrupto poder marítimo, financiero y colonial seguían aportando benefícios económicos tangibles que, a menos que avancemos años y consideremos sus resultados a largo plazo, debemos reconocer" (Kemp, 1987, p. 68).

Antes de avançarmos, convém ressaltar algo importante: o capital, quanto mais fortemente inserido em determinada formação social, mais consegue determinar suas dinâmicas política, econômica e social, mesmo que o processo de industrialização ainda não tenha se completado minimamente. Lembremos, a Segunda Revolução Industrial foi gestada nos “Anos de Ouro" e parida na "Grande Depressão", mas só cresceu e se desenvolveu como processo essencialmente diferente da primeira fase de industrialização com a efetiva mudança no padrão de acumulação capitalista, por conta da sua primeira mundialização. Esse processo, imposto de forma exógena, é parte do que chamamos de Imperialismo Capitalista.

\section{Navegação transoceânica a vapor}

O desenvolvimento da navegação a vapor não se principiou na Inglaterra, mas teve lá os seus mais frutíferos resultados. A princípio, o próprio James Watt duvidava da aplicação da máquina a vapor nas embarcações marítimas. Um século mais tarde, com os aperfeiçoamentos feitos pelos seus sucessores, foi apresentada, na exposição industrial de Londres, em 1851, a mais colossal máquina a vapor para os ocean steamers (transoceânicos a vapor).

O industrial inglês Bennet Woodcroft, em um estudo pioneiro (1848), não só aclarou esse processo, como disseminou apologeticamente os resultados das incipientes experiências com os vapores na navegação. Parte deles está expressa numa tabela com todas as patentes concedidas na Inglaterra que tivessem como objeto a propulsão de embarcações. O 
crescimento escalar é prova que o fenômeno de "tentativa e erro", típico da Revolução Industrial em sua primeira fase, grassou na navegação. Durante a década de 1830, quando a primeira embarcação a vapor cruzou o oceano Atlântico, o número de patentes concedidas já era duas vezes maior que durante os séculos XVII e XVIII juntos (Woodcroft, 1848, p. 422-440).

Mas isso não quer dizer que a base material-técnica da navegação tenha sido substancialmente modificada nesse momento. A grande resiliência dos barcos à vela impressiona, sua capacidade de transformação e melhoramento foi responsável pela demorada generalização da navegação a vapor:

Complemento de los ferrocarril es fueel barco a vapor, sistema de transporte iniciado em los Estados Unidos hacia 1800 pero incapaz de competir seriamente com el barco de vela, cada vez más eficaz, hasta la transformación revolucionaria de los produtos de base, pilares de la economia industrial, que la era del ferrocarril inauguraba. (Hobsbawm, 1982, p. 109)

Dessa forma, consideramos estabelecido que a navegação, especialmente na forma marítima, colaborou com o desenvolvimento do capitalismo e para a irrupção da Revolução Industrial, mas também foi modificada nesse processo.

Uma série de estudos, memórias, projetos, relatórios etc. de época apontam que a generalização das embarcações a vapor se deu primeiro nas navegações interna, de serviço portuário e de cabotagem, sendo predominante nos mares e oceanos apenas no último quartel do século XIX. Embora os rios, baías e costas tivessem sido importantes laboratórios do desenvolvimento da navegação a vapor, questionamo-nos por que as repercussões dos vapores na navegação marítima foram tão mais significativas. Teria havido uma revolução industrial nos mares? E, mais, até que ponto esse processo colaborou para o imperialismo de tipo capitalista?

De fato, as embarcações se tornaram verdadeiros colossos, seu tamanho, estabilidade, autonomia, capacidade de carga, segurança e previsibilidade eram tão maiores quanto mais a maquinofatura se imiscuía no processo de produção dos "paquetes" e em sua própria operação.

O Quadro 1 demonstra esse processo. Os números impressionam, em pouco mais de 60 anos, a profundidade da maior embarcação em 
atividade nas linhas transoceânicas cresceu em $62 \%$,já o comprimento dessas naves gigantes aumentou em 192\%! O dado que nos parece definitivo é o incremento da capacidade de carga, em pouco mais de um século, resultou num aumento de $1.441 \%$ !

Quadro 1 - Maiores embarcações no serviço transoceânico

\begin{tabular}{|c|c|c|c|c|c|c|}
\hline ANo & Nome & MATERIAL & $\begin{array}{c}\text { COMPRIMENTO } \\
\text { (PÉS) }\end{array}$ & \begin{tabular}{|c|}
$\begin{array}{c}\text { PROFUNDIDADE } \\
\text { (PÉS) }\end{array}$ \\
\end{tabular} & TONELADAS & Proprietário \\
\hline 1793 & $\begin{array}{l}\text { Warren } \\
\text { Hasting }\end{array}$ & Madeira & & & 1.356 & East India Company \\
\hline 1811 & $\begin{array}{l}\text { Lowther } \\
\text { Castic }\end{array}$ & Madeira & & & 1.507 & East India Company \\
\hline 1838 & $\begin{array}{l}\text { British } \\
\text { Queen }\end{array}$ & Madeira & 234 & 27 & 2.016 & $\begin{array}{l}\text { The British and } \\
\text { American Steam } \\
\text { Navigation Company }\end{array}$ \\
\hline 1843 & $\begin{array}{l}\text { Great } \\
\text { Britain } \\
\end{array}$ & Ferro & 274 & 31 & 3.270 & $\begin{array}{l}\text { Great Western } \\
\text { Steamship Company }\end{array}$ \\
\hline 1853 & Himalaya & Ferro & 340 & 31 & 3.438 & $\begin{array}{l}\text { Peninsular and Oriental } \\
\text { Steam Navigation } \\
\text { Company }\end{array}$ \\
\hline 1859 & Seine & Ferro & 331 & 33 & 3.440 & $\begin{array}{l}\text { Royal Mail Steam } \\
\text { Packet Company }\end{array}$ \\
\hline 1862 & Scotia & Ferro & 379 & 47 & 3.871 & Burns \& McIver \\
\hline 1871 & Egypt & Ferro & 440 & 44 & 4.670 & $\begin{array}{l}\text { National Steamship } \\
\text { Company }\end{array}$ \\
\hline 1873 & Hooper & Ferro & 338 & 34 & 4.907 & $\begin{array}{l}\text { Hooper's Telegraph } \\
\text { Works }\end{array}$ \\
\hline 1874 & Britannic & Ferro & 455 & 33 & 5.004 & $\begin{array}{l}\text { Oceanic Steam } \\
\text { Navigation Company }\end{array}$ \\
\hline 1875 & $\begin{array}{l}\text { City of } \\
\text { Berlin }\end{array}$ & Ferro & 488 & 34 & 5.491 & $\begin{array}{l}\text { Inman Steamship } \\
\text { Company }\end{array}$ \\
\hline 1881 & $\begin{array}{l}\text { City of } \\
\text { Rome }\end{array}$ & Ferro & 560 & 37 & 8.144 & $\begin{array}{l}\text { Inman Steamship } \\
\text { Company }\end{array}$ \\
\hline 1889 & \begin{tabular}{|l|} 
City of \\
New York
\end{tabular} & Aço & 527 & 39 & 10.499 & $\begin{array}{l}\text { Inman Steamship } \\
\text { Company }\end{array}$ \\
\hline 1889 & $\begin{array}{l}\text { City of } \\
\text { Paris }\end{array}$ & Aço & 527 & 39 & 10.499 & $\begin{array}{l}\text { Inman Steamship } \\
\text { Company }\end{array}$ \\
\hline 1893 & Lucania & Aço & 601 & 37 & 12.952 & $\begin{array}{l}\text { Cunard Steamship } \\
\text { Company }\end{array}$ \\
\hline 1899 & Oceanic & Aço & 685 & 44 & 17.274 & $\begin{array}{l}\text { Oceanic Steam } \\
\text { Navigation Company }\end{array}$ \\
\hline 1900 & Celtic & Aço & 681 & 44 & 20.904 & $\begin{array}{l}\text { Oceanic Steam } \\
\text { Navigation Company }\end{array}$ \\
\hline
\end{tabular}

Fonte: Owen (1904, p. 69). 
A generalização da navegação a vapor, dos materiais de ferro e, especialmente, do casco de aço ${ }^{1}$ fizeram da construção naval um esforço constante de desenvolvimento das forças produtivas capitalistas. A Revolução Industrial nos transportes de longa distância, que acontece no âmbito do que chamamos de Segunda Revolução Industrial, constituiu importante avanço técnico e tecnológico com o objetivo de garantir a efetivação dos seus capitais e mercadorias em territórios cada vez mais distantes, reflexo direto do imperialismo.

A própria adoção generalizada do ferro na parte mais substantiva das embarcações, o casco, foi ocorrer apenas na segunda metade do século, sendo substituída pelo aço logo após: "O primeiro barco de aço é de 1863 e, em 1874, o aço substitui completamente o ferro [na construção naval], o uso de turbinas de vapor e motores diesel completou a transição para o barco moderno" (Iglésias, 1981, p. 55).

Os motores de expansão tripla e quádrupla só puderam ser construídos graças à adoção da propulsão por hélice, substituindo as rodas de pás. As máquinas de hélices eram de movimento direto, permitindo uma economia de espaço e equipamentos que viabilizou o acréscimo da expansão já no final da década de 1850. A expansão dupla teve adoção mais rápida nas embarcações que nas fábricas; sua usina de força tinha de ser maior e mais potente; a economia de combustível era crucial, quanto mais espaço se desperdiçava com carvão, menos mercadorias poderiam ser transportadas. Vale lembrar-se da verdadeira revolução que fora a introdução dos guindastes a vapor no convés dos transatlânticos.

O desperdício e o alto consumo de combustíveis eram, provavelmente, os maiores entraves para a adoção generalizada dos vapores transoceânicos. Desde os sais encrostados no maquinário e no próprio carvão até o exigente sistema de máquinas adotado, muitos fatores agiam sobre a embarcação a vapor exigindo estoque e desperdiçando grande quantidade de carvão. $\mathrm{O}$ que criava inconvenientes como a limitação de espaço das embarcações, os perigos em seu acondicionamento e as inúmeras escalas para reabastecer, especialmente nas ilhas atlânticas.

$\mathrm{Na}$ contramão dessa tendência, as caldeiras tubulares, criadas na década de 1860, acresciam e concentravam a força necessária para mover

1 O aço, ao mesmo passo que é mais resistente, também contribuía para a possibilidade de variação do lastro e para a economia de espaço na embarcação, por conta sua maleabilidade. 
as novas máquinas de cilindros oscilantes, em alta pressão, utilizando menos combustível para uma outra escala de força. $\mathrm{Na}$ mesma época, o condensador de superficie, sem demandar de muita água doce, conseguiu diminuir sensivelmente a temperatura externa das caldeiras, além de concentrar os vapores nos bocais de saída. Esses inventos foram necessários para aumentar o desempenho e garantir a segurança nas viagens.

O engenheiro português Carlos Augusto Pinto Ferreira, que nos legou importante estudo sobre as máquinas de vapor marítimas (1888), fez um apanhado histórico do avanço técnico-tecnológico:

1. Suppressão das machinas de balanceiros lateraes empregadas no movimento das rodas de pás, e substituirão por machinas de differentes systemas de movimento directo, sendo as mais importantes as de cylindros oscillantes de John Penn;

2. Adopção da caldeira americana multitubular, e na mesma epocha a applicação prática da helice como propulsor;

3. Melhoramentos no condensador de superfície de Hall e sua adopção;

4. Augmento progressivo da pressão do vapor nas caldeiras, sua construccção mais resistente e emprego de maior grau de expansão nas machinas; 5. Transformação das machinas de baixa pressão em machinas do systema de Woolf, ou de alta e baixa pressão, e a construcção de caldeiras cylindricas para pressões elevadas. (Pinto Ferreira, 1888, p. 26-27)

Pinto Ferreira (1888, p. 27) ainda registra dados absolutamente relevantes, que comprovam a eficácia do expressivo avanço das forças produtivas nos mares entre as décadas de 1840 e 1880: nos princípios da navegação a vapor transoceânica, o consumo médio do carvão era de 3 quilogramas para cada cavalo de força, 40 anos depois passou a ser de 1 quilograma para cada cavalo de força; assim como as máquinas marítimas não passavam de 500 cavalos de força na década de 1840, chegando a incríveis 6.000 cavalos de força ao final da década de 1880 !

O último desenvolvimento dos transoceânicos a vapor no Oitocentos foi a turbina marítima, invenção da fábrica de Hon Parsons. O seu mecanismo é complexo, aproveitando-se do vácuo gerado nas embarcações já em movimento para adição de sua própria propulsão. $\mathrm{O}$ primeiro navio equipado com esse novo tipo de motor era o Turbina, essa embarcação protótipo já era dez vezes mais rápida que as similares. Embora o peso de seu maquinário fosse de apenas 26 toneladas, ela comportava 
2.600 cavalos de força, ou seja, força de um motor médio para o peso de uma pequena embarcação. Os primeiros testes feitos na embarcação, no rio Tyne, alcançaram incríveis $62 \mathrm{~km} / \mathrm{h}$ ! O primeiro transatlântico mercante a estar equipado com a turbina era o King Edward, construído pelo estaleiro Denny Brothers e de propriedade da Oceanic Steam Navigation Company em 1901 (Kennedy, 1903, p. 157).

Segundo Suárez Bosa (2013), esse crescimento da navegação a vapor tinha os seguintes efeitos: o aumento considerável do número de passageiros e volume de carga; a criação de uma contínua, e em crescente expansão, rede de transportes internacional para garantir o permanente fluxo de mercadorias, capitais e pessoas; e essa revolução no transporte marítimo e terrestre pressionou por melhorias nos acessos aos portos e a consequente ampliação no seu espaço para facilitar a recepção e mobilidade dos grandes navios, condicionando a localização dos terminais de terra, canais e redes ferroviárias.

Suárez Bosa nos fornece números diferentes de Cipolla. Para ele, já na década de 1870, o vapor superou (com o dobro de carga a mais) a vela nas viagens transatlânticas (Suárez Bosa, 2013, p. 5-6). Afastamos a polêmica e temos claro que os números de Cipolla são mundiais, concluímos, disso, que no atlântico as viagens transoceânicas a vapor se generalizaram antes do que nos outros oceanos.

Gráfico 2 - Capacidade de todas as máquinas a vapor (em milhares de cavalos a vapor e em milhares de tonelagem bruta)

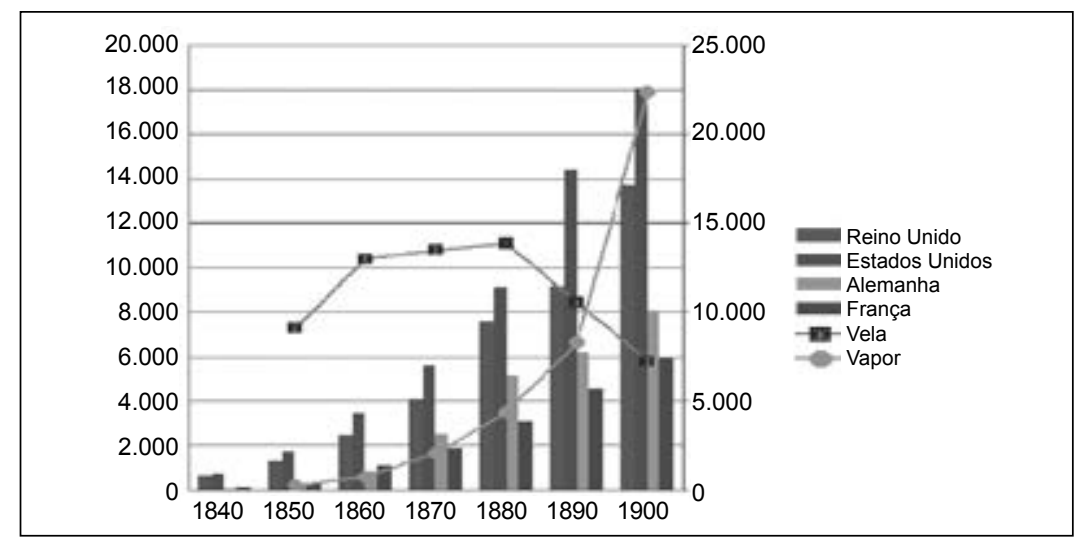

Fonte: Cipolla (2013, p. 60, 86). 
Analisando o Gráfico 2, fica clara a associação entre a navegação a vapor e o aumento do número de cavalos-força utilizados nos principais países que lideravam a produção dessa fonte de energia, legada ainda pela Primeira Revolução Industrial.

O contra-almirante americano George Henry Preble (1881), em seu relatório sobre a navegação a vapor para o governo norte-americano, feito em princípios da década de 1880, confirma algumas de nossas noções. Em um levantamento completo das perdas na frota mundial de navios a vapor, Preble (1881, p. 266-271) contabilizou 145 unidades perdidas entre os anos de 1841 e 1879.

Os navios perdidos tinham média de 4,5 anos de utilização, ou seja, havia uma taxa de renovação razoável da frota, sendo raros os casos de naves com mais de 10 anos de utilização. Um percentual de $67,5 \%$ dos navios foi perdido na década de 1870, entretanto apenas $42 \%$ dos navios perdidos foram construídos na década de 1870 . Os casos extremos do Missouri e do City of Washington, que foram perdidos 18 anos após a sua construção, demonstram o impulso gerado pela Grande Depressão no comércio internacional. A necessidade de exportar mercadorias e capitais chegou ao ponto de tornar as viagens tão mais frequentes quanto perigosas, criando a necessidade de reforma das embarcações antigas, colocando-as em serviço de forma precária e insegura.

As expressivas perdas atestam que os 40 anos retratados foram de uma transição frenética da base técnica-tecnológica na navegação. Boa parte das tentativas de inovação claramente falhou, as 145 unidades perdidas submergiram com 246.360 toneladas de objetos (correspondências, moedas, mercadorias, etc.) e, no mínimo, 4.107 pessoas (a maioria tripulantes). O baixo número de pessoas perdidas é relativo, pois se dá por conta de 3 razões: 23 das 145 perdas constam como "todas as pessoas perdidas", sem registro quantitativo, especialmente nas décadas de 1850 e 1860; na década de 1870, aperfeiçoaram-se as técnicas de resgate; e, especialmente, porque o contingente da marinharia por unidade, como já deixamos claro, decresceu a olhos vistos em nosso recorte.

Outro dado importante confirma a hegemonia do oceano Atlântico nas travessias transoceânicas: $98 \%$ das viagens perdidas estavam programadas com partidas e destinos entre portos atlânticos de continentes distintos. Entretanto, apenas 5,5\% das perdas se deram em alto-mar; mais comuns eram as perdas em acidentes próximos aos cabos $(6,8 \%)$, às ilhas 
$(6,8 \%)$ e à costa ou mesmo aos portos continentais $(13,7 \%)$. Os naufrágios por colisão eram a motivação mais comum para as perdas, especialmente no Atlântico Norte. No geral os naufrágios correspondiam a $57,9 \%$ das perdas, enquanto os desaparecimentos eram de $17,2 \% ; 11,7 \%$ foram a pique por incêndios e 8,2\% foram afundados por força militar. Ou seja, o maior risco nessas viagens era de colidir com um banco de areia, uma montanha de pedras, uma geleira ou mesmo com outra embarcação naufragada não em alto-mar, e sim próximo à terra firme. Podemos entender isso como consequência imediata do agigantamento das embarcações, que impactava na necessidade de melhorias infraestruturais nas costas e nos portos.

Outro dado que podemos extrair do levantamento de Preble envolve a bandeira e a nacionalidade das embarcações perdidas, as quais $75 \%$ eram de bandeira britânica e 95\% do total foram construídas na Grã-Bretanha!

Já na década de 1850, Thomas Rainey, crítico do atraso tecnológico norte-americano, atentava para a dependência que os Estados Unidos sofriam das empresas de correspondência e frete inglesas. Além disso, também apontava para os novos padrões de deslocamento no espaço marítimo, comparando as condições entre os navios a vela e os vapores:

The steam marine of the United States, postal, mercantile, and naval, is today so insignificant in extent that we do not feel entirely certain that it is a sufficient nucleus for the growth of a respectable maritime power. The few ships that we possess are among the fleetest and the most comfortable that traverse the ocean, and have excited the admiration of the world wherever they have been seen. But their number is so small, their service so limited, their field of operation so contracted, that our large commerce and travel are dependent, in most parts of the world, on British steam mail lines for correspondence and transport, or on the slow, irregular, and uncertain communications of sailing vessels. (Rainey, 1858, p. 23)

Esse processo de transformação da navegação marítima foi liderado, insistimos, de forma inconteste pela Inglaterra. Com a crescente concorrência americana e alemã em outros ramos industriais, a construção naval e a própria Marinha Mercante inglesa foram ganhando cada vez maior importância (Hobsbawm, 1982, p. 139). 


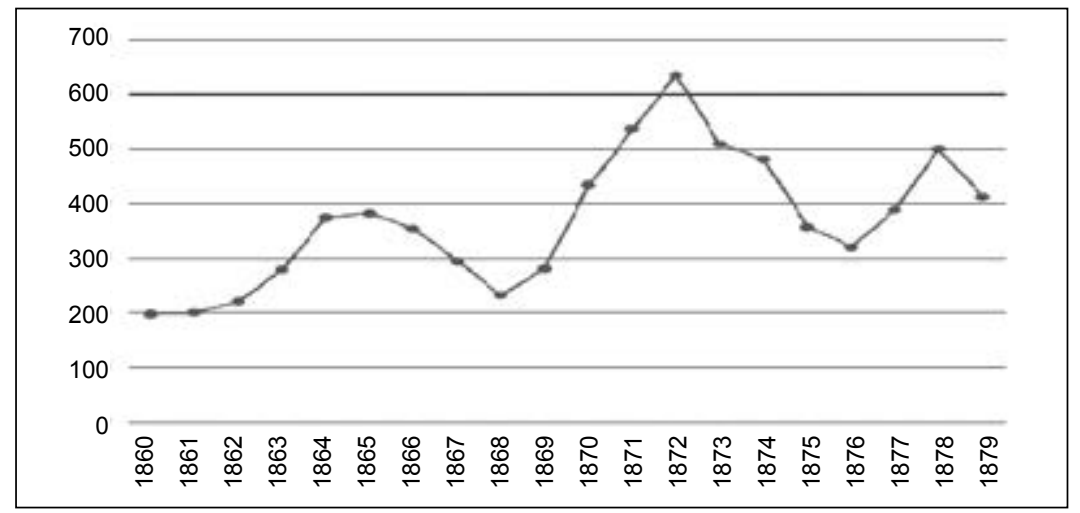

Fonte: Preble, (1881, p. 192).

O transporte marítimo, mais eficiente do que nunca, levou a um aumento acentuado da capacidade do comércio internacional, o que era compatível com os desafios de fazer transportar bens de capital, e a uma queda correspondente da taxa de frete, que mesmo assim fazia exponenciar os lucros da Marinha Mercante inglesa, sendo isso importantíssimo para o fechamento positivo da sua balança de pagamentos. O Gráfico 4 demonstra a vantagem britânica na disputa pelos mares, exatamente no momento do crash da Bolsa de Viena, que inicia a Grande Depressão.

Gráfico 4 - Frotas mercantes a vapor por nacionalidade, 1873

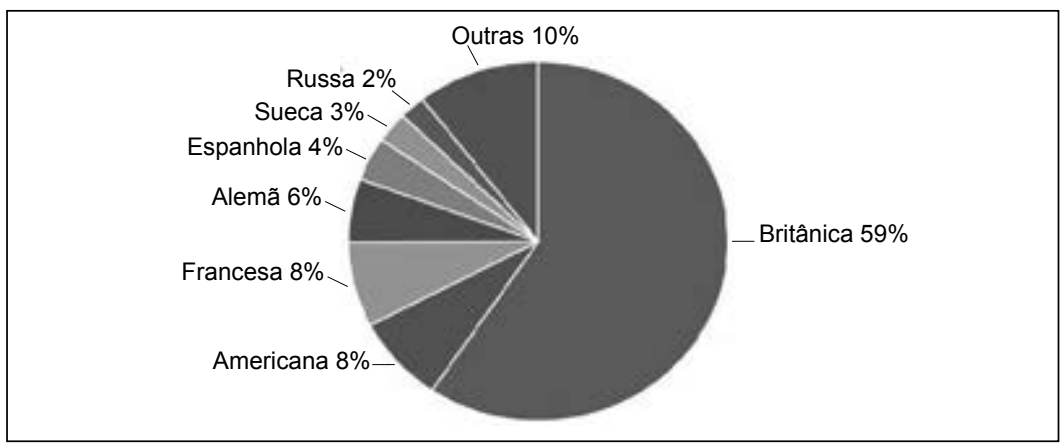

Fonte: Preble (1881, p. 179).

Outra tabela fornecida por Preble é de extrema importância para 
nós, pois suas informações dizem respeito às dez maiores companhias de exploração das linhas transoceânicas a vapor.Além de suas informações em si, podemos compará-la com outras fontes e trazer um retrato fiel da mutação operada pelas principais empresas capitalistas que utilizavam de navios a vapor em suas atividades.

Tabela 3 - Maiores companhias de navegação transoceânica a vapor, 1858

\begin{tabular}{l|l|c|c|c}
\hline \multicolumn{1}{c|}{ COMPANHIA } & BANDEIRA & FUNDAÇÃO & EMBARCAÇÕES & TONELAGEM \\
\hline Messageries Maritimes & Francesa & 1835 & 50 & 60.000 \\
\hline $\begin{array}{l}\text { Peninsular and Oriental } \\
\text { Steam Navigation Company }\end{array}$ & Britânica & 1836 & 39 & 49.416 \\
\hline Royal Mail Steam Packet & Britânica & 1841 & 22 & 28.330 \\
\hline $\begin{array}{l}\text { Pacific Mail Steam } \\
\text { Navigation Company }\end{array}$ & Britânica & 1838 & 13 & 16.421 \\
\hline Cunard Line & Britânica & 1840 & 12 & 16.800 \\
\hline East India Company & Britânica & 1600 & 12 & 11.471 \\
\hline Burns \& McIver & Britânica & 1841 & 12 & 11.000 \\
\hline Bibby's Line & Britânica & 1801 & 10 & 11.700 \\
\hline $\begin{array}{l}\text { European \& American } \\
\text { Steamship Company }\end{array}$ & Americana & 1857 & 8 & 19.000 \\
\hline $\begin{array}{l}\text { European and Australian } \\
\text { Royal Mail Company }\end{array}$ & Britânica & 1852 & 7 & 15.500 \\
\hline
\end{tabular}

Fonte: Preble (1881, p. 171).

Como não podemos deixar de notar, oito das dez maiores companhias de transatlânticos a vapor eram britânicas. A metade se concentrava no transporte transatlântico, a outra metade se dividia entre o mar Mediterrâneo e os oceanos Pacífico e Índico. Certamente que a East India Company é uma exceção, como grande exploradora colonial que não se atinha à navegação. Todas as outras eram empresas transportadoras transoceânicas e marítimas, quatro exclusivamente de fretes e seis mistas: faziam fretes, entregavam correspondências e transportavam passageiros.

Transportar se tornou uma importante fonte de lucros, como registrava o economista William Cunningham: "The business of carrying became more completely differentiated from that of trading in goods, and companies were formed to organise and maintain fleets of steamers and sailing-vessels, which should ply at regular intervals between definite ports" (Cunningham, 1917, p. 817). 
Gráfico 5 - Década de fundação das maiores companhias de navegação transoceânica, 1901

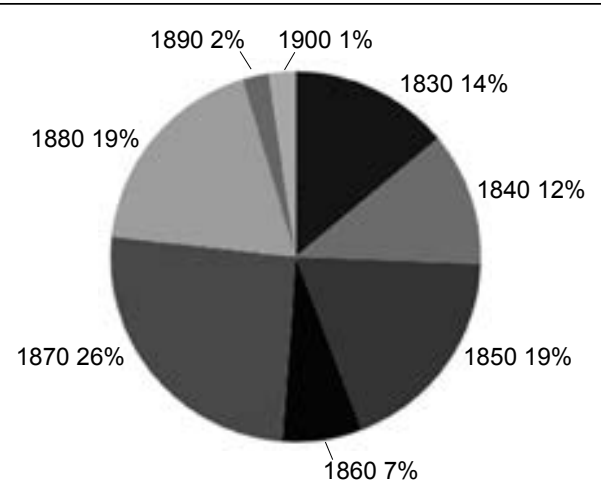

Fonte: Journal of the Royal Statistical Society (1901).

A partir do Quadro 1 e da Tabela 3, podemos ter certeza de que os serviços postais, de instalação de cabos telegráficos submarinos e de malas diplomáticas foram importantes impulsionadores da navegação transoceânica a vapor nas décadas de sua introdução. Até a década de 1870 , enquanto a maior parte dos fretes de cargas eram movidos através da força dos ventos, as cartas, os jornais e as comunicações no geral já demandavam da velocidade dos vapores.

Nesse sentido, a tabela fornecida pelo Journal of the Royal Statistical Society, no alvorecer do século XX, é absolutamente reveladora. Dessa importante fonte, tiramos os subsídios para alguns gráficos e informações que se seguem, podendo compará-los com outras. O jornal dedicou toda uma edição com 6 ensaios para analisar uma tabela intitulada "Shipping subisidies", nela constam as 43 maiores empresas de navegação transoceânica do mundo, sendo discriminadas por sua bandeira, sua data de fundação, pelo número de embarcações a vapor que operava, assim como por sua capacidade total de carga em 1891 e 1901. Temos claro que a fonte já nos lega um processo consolidado, mas, se a combinarmos com as análises, os dados, os gráficos, as tabelas e os quadros que já exibimos aqui, boa parte da nossa argumentação parece amplamente confirmada (Journal of the Royal Statistical Society, 1901).

Com relação à fundação dessas companhias, fica patente que as décadas de 1830,1840 e 1850 viram surgir quase a metade dessas empresas. 
Essa informação é coerente com a constatação de Marx sobre a verdadeira revolução que a indústria acarretou na navegação a vela; todo o processo que aqui expomos levou à criação desses gigantes dos mares antes mesmo da navegação a vapor.

As informações prestadas pelo contra-almirante Preble também são compatíveis com a tabela do jornal, 8 das 10 maiores empresas de transoceânicos a vapor, em 1858, constam na tabela apresentada mais de 40 anos depois. Não surpreende que o avanço nas forças produtivas tenha transitado exatamente pelas mãos das mesmas companhias. No caso da navegação, a especificidade de não demandar de uma planta fabril fixa, além de poder remodelar e ampliar suas unidades produtivas (as embarcações) com certa facilidade (seja por encomenda, ou com ampliação dos seus estaleiros), e os vultosos lucros do frete em um momento de franco crescimento do comércio internacional explicam o fato das maiores companhias de navegação a vapor, do final do século, terem se utilizado largamente da vela em sua gênese.

Além do mais, a especificidade técnica da navegação marítima permite a complementaridade de duas bases de força: por propulsão e motriz. O primeiro navio a vapor, criado pelo americano Robert Fulton, a atravessar o oceano Atlântico foi o Savanaah em 1819, saindo de Nova York e chegando em Londres após quase um mês. A maior parte da viagem foi feita, entretanto, ainda pela força dos ventos (Morrison, 1908, p. 407).

Apenas em 1838, deu-se a travessia completa com base na nova tecnologia, e o pequeno vapor Sirius partiu de Londres em pouco mais de 20 dias. Com suas grandes rodas de pás movendo-se pelos vapores, transformou-se no primeiro navio a cruzar o Atlântico com força predominantemente motriz. Algumas horas depois, o muito maior Great Western, construído pelo renomado engenheiro Isambard Kingdom Brunel, completou a mesma façanha, entretanto com uma capacidade de carga e passageiros muito maior. Construído no estaleiro de Patterson \& Mercer, em Bristol, o Great Western carregava 1.979 toneladas e trafegava com velocidade de 8,66 nós $(16,04 \mathrm{~km} / \mathrm{h})$, fazendo a travessia transatlântica em 15 dias e 12 horas. Esta foi a primeira nave construída com popa redonda e fundo sólido (Fry, 1883, p. 7).

Apenas em 1840, a The British and North American Royal Mail Steam-Packet Company, fundada por Samuel Cunard, conseguiu esta- 
belecer uma linha regular de vapores entre Liverpool e Nova York. O primeiro vapor da dita linha foi o Britannia, que carregava 1.156 toneladas e tinha capacidade para 65 passageiros, além da tripulação (Bowen, 1930, p. 38-42).

Em 1838, o canadense Samuel Cunard foi para a Inglaterra e apresentou-se ao Sr. Robert Napier, experiente engenheiro de Glasgow, e fez um pedido para construir 4 embarcações de vapor para o serviço no Atlântico. Foi acordado que os 4 navios deveriam ter uma carga de 1.200 toneladas e 440 cavalos de potência. Para atrair recursos, fundaram a The British and North American Royal Mail Steam-Packet Company e conseguiram um contrato com o governo britânico de 7 anos para o transporte de correspondências estatais entre Liverpool e Halifax, Boston e Quebec. A primeira concessão de serviço público do transporte transoceânico por navios a vapor da história foi contratada por 60.000 libras anuais (Foster, 1884, p. 330).

Desde o ano de 1840 até o início da década de 1880, as diversas companhias do Sr. Cunard construíram 122 vapores. Em 1858, os Cunards possuíam 12 naves a vapor, carregando 16.800 toneladas; em 1884, sua frota era de 30 navios a vapor, com uma tonelagem de 69.604 toneladas e contendo 44.445 cavalos de potência (Foster, 1884, p. 346-347). Apesar desse pioneirismo, dos grandes e velozes navios que possuía, a linha do Sr. Cunard aparece na lista do jornal de estatística em uma modesta colocação, reduzida a 22 embarcações, em 1891, e 26, em 1901.

Pouco a pouco as linhas dos "capitães de indústria" como os senhores Cunard, Allan, Bibby, McIver, Collins, Wilson etc. foram se transformando em grandes companhias na forma de sociedades anônimas e/ ou permanecendo como empresas de responsabilidade limitada. As empresas que decidiram não se inserirem na nova lógica monopolística, mesmo que parcialmente, perderam espaço para os monopólios em formação. Nesse processo, surgem as sociedades anônimas gigantes nos mares, através de fusões, absorções, associações etc. entre empresas médias e grandes. Aqueles industriais (especialmente ingleses) que resolveram continuar a sua gestão individualmente, além das novas forças de trustes e cartéis, passaram a se defrontar com uma série de novas empresas médias, criadas com capitais empatados com a crise iniciada em 1873.

No Gráfico 6, também se constata uma grande concentração de fundações dessas empresas nas décadas de 1870 e 1880, com um grande 
recuo na década seguinte. Apesar de tempos identificados com a Grande Depressão e a concentração de capitais, o gráfico demonstra a criação de uma série de médias empresas de navegação que já nascem utilizando largamente o vapor. É possível que a maior parte dessas empresas tenha fugido ao olhar da sociedade de estatística britânica; dessa forma, podemos supor que o processo foi ainda mais acentuado.

Parece-nos que esse dado é definitivo para a conclusão sobre a grande demanda criada pelo imperialismo. Se, por um lado, é fato que as companhias já estabelecidas vão crescer, concentrar capital, centralizar maior número de unidades produtivas e trabalhadores, tornar mais complexa sua divisão do trabalho, mais profissional a sua organização administrativa e mais poderosos os seus interesses, também é verdade que os impérios criados ou fortalecidos durante a Grande Depressão (com a tendência ao desenvolvimento da indústria em áreas periféricas da Europa, nos Estados Unidos e no Japão) vão demandar modernos meios de transporte para efetivar suas exportações de capitais nas sobreditas zonas de influência.

Gráfico 6 - Maiores companhias de navegação transoceânica por nacionalidade, 1901

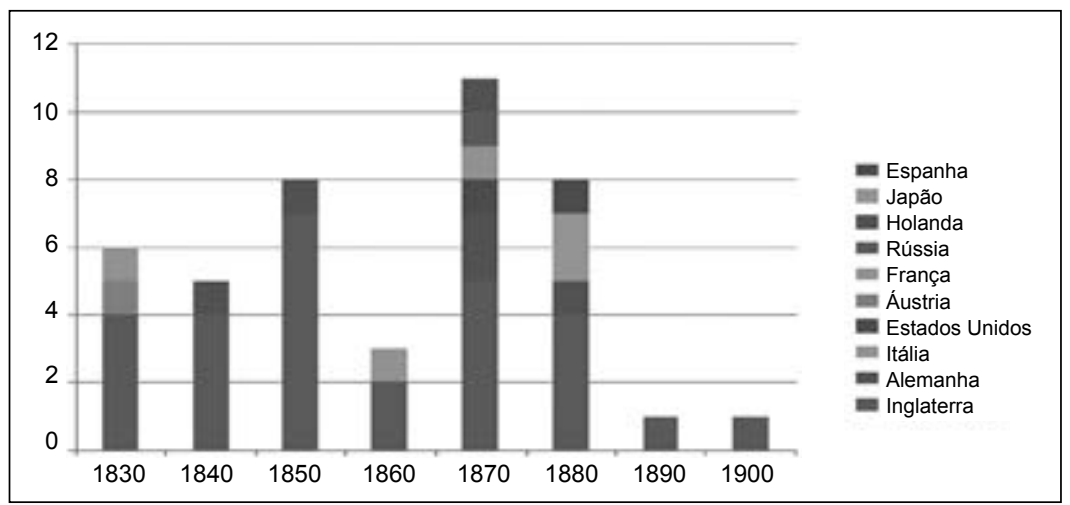

Fonte: Journal of the Royal Statistical Society (1901).

As novas exigências do mercado mundial vão forçar a criação de empresas de navegação a vapor em outros países. A concorrência com os grandes colossos ingleses e alemães só se sustentou por conta dos benefícios e isenções que essas "empresas nacionais" desfrutavam para além da larga execução de práticas monopolísticas. 
Não à toa, no Gráfico 6, as colunas da década de 1870 e 1880 são mais coloridas, a presença constante da Inglaterra, como grande incubadora de companhias de navegação, durante todo o período, apenas confirma o que temos dito a respeito da importância de sua Marinha Mercante; entretanto, nas décadas de 1870 e 1880 o panorama se encontra mais dividido, especialmente os alemães, mas, também americanos, franceses, holandeses, espanhóis, italianos, austríacos, russos e japoneses passam a comandar suas frotas a vapor. Como bem registra Lenin, no final do século XIX e alvorecer do século XX, a importância inglesa nos mares será diminuída pela entrada dos grandes oligopólios alemães e americanos no setor (Lenin, 2013, p. 195-196).

Foram necessárias algumas décadas para que a chamada "partilha do mundo" também significasse uma "partilha dos mares". Nos Estados Unidos, por exemplo, o banqueiro Morgan comprou boa parte das companhias transatlânticas norte-americanas e algumas inglesas, como testemunha Lenin. A principal delas era a White Star Line, comprada por 32 milhões de dólares (Kennedy, 1903, p. 314). Essa empresa era reconhecida pela comodidade em suas instalações para passageiros de primeira classe e pela velocidade de seus paquetes (Preble, 1881, p. 243).

Outro aspecto que tem de estar suficientemente claro é que esse processo não se deu de forma "livre". As forças imperialistas, amparadas em seus Estados Nacionais, atuaram internamente para que a concorrência nos mares fosse vedada ao máximo. Nesse sentido, a atuação das "conferências" consubstanciou aquilo que chamamos de "partilha dos mares”. Essas organizações políticas dos armadores objetivavam manter o frete marítimo e o próprio mercado sob seu restrito controle, uma clara forma de cartelização. Segundo um perspicaz observador de época define:

Shipping conferences. These are usually agreements to maintain rates upon a certain route. Once the carriers have agreed, they usually arrange a schedule of sailings, rendering the best possible service, and keep off competitors by a system of deferred rebates. This is usually ten per cent. of the freight. It is calculated at the end of a long period, usually six months. and paid six months. or a year later, provided the shipper has remained "loyal" to the members of the conference. Shipping by a rival line is, of course, "disloyalty," so that the conference carriers, by means of these deferred rebates, practically keep all regular shippers under bonds to let all 
rivals severely alone.Thus is the shipper bound.The starting of rival shipping lines is deterred by the certainty of fierce competition, and by the restraining tendency which the rebates will have on the people who; would otherwise ship by the new line. (Russell Smith, 1906, p. 533)

Essa "partilha dos mares" não era um fenômeno feito secretamente. De forma aberta, inclusive com a cobertura da imprensa, os presidentes das principais companhias de navegação transoceânica se reuniam no Annual General Meeting of the Shipping. Foi durante um desses encontros, já no ocaso do século XIX, que Sir Thomas Sutherland, presidente e maior acionista da Peninsular \& Oriental Company, proferiu a seguinte sentença:

Não era possível dirigir com lucro uma empresa de navegação sem uma uniformidade de tarifas, estabelecida por uma "conferência" das companhias transportadoras. Essas conferências poderiam ser comparadas aos acordos que existiram entre as várias companhias ferroviárias do Reino Unido. As ferrovias cobravam tarifas idênticas entre os mesmos pontos, embora mantendo a competição no terreno da velocidade, da acomodação oferecida nos trens e nas facilidades gerais. Foi isso exatamente o que as companhias de navegação fizeram. (Hobson, 1983, p. 131-132)

Exatamente nesses encontros anuais que eram distribuídos os prêmios para as embarcações que alcançavam a Blue Riband, atingindo a marca de embarcação mais veloz na travessia atlântica. Esse prêmio era uma forma de as "conferências" promoverem seus próprios feitos e justificarem o preço combinado dos fretes. Os armadores justificavam a cartelização com a máxima: "Ganha mais quem é mais veloz e tem maior capacidade de carga".

Em suas memórias, o armador Robert Dollar, proprietário da Pacific Mail Steamship Company, assume apaixonadamente a hipótese formulada pelo cartel dos mares:

The competition on the Atlantic was so intense that naval architects and marine engineers were kept on their toes to improve the performance of their new ships. Speed was the great necessity; and a ship that could capture the blue ribbon was the dream of every owner. (Dollar, 1931, p. 73) 
Evidentemente que a análise de Dollar está carregada de vícios. A competição que havia era absolutamente controlada e o mercado de frete, assim como as linhas fixas, cada vez mais monopolizados.

De toda forma, o industrial registra os números da Blue Riband, que são interessantes para nossa avaliação (Dollar, 1931).É curioso notar que entre o Sirius, primeiro premiado em 1838, e o Lucania, premiado em 1894, todas as 23 embarcações premiadas eram de bandeira britânica. É sintomático que, em 1898, o KaiserWilhelm der Grosse tenha desbancado os britânicos, sendo o primeiro alemão a levar prêmio, pois esse navio era propriedade de um dos Lloyds alemães, o de Bremem. Esse fato demonstra o que Lenin explana em seu opúsculo, além ratificar a hipótese de que a Segunda Revolução Industrial anda de braços dados com o Imperialismo Capitalista, alargando as áreas industrializadas no globo e multiplicando as potências no centro do sistema.

Entre o Sirius e o Deutschland, vigésima quinta e última embarcação premiada do século XIX, a velocidade máxima foi incrementada em $200 \%$, diminuindo em $72 \%$ o tempo de viagem no intervalo de 62 anos da experiência dos vapores transoceânicos.

Dessa forma, o incremento da capacidade de carga se deu por diversas vias: as frotas mercantes cresceram sistematicamente, Bukharin (1984, p. 118) registra que, entre 1872 e 1907, a frota mercante inglesa foi acrescida em 184\%, a Alemã, em 281\% e a francesa, em 70\%; as embarcações se tornaram sistematicamente maiores e tinham seu espaço otimizado, como vimos no Quadro 1, e o número de viagens aumentava freneticamente, especialmente pela velocidade aplicada aos novos paquetes. O resultado desse processo está expresso, mesmo que parcialmente, no Gráfico 7.

Apesar dos números quantitativos gerais previsíveis para os avançados anos de 1891 e 1901, como o crescimento expressivo e concentrado tanto das frotas quanto da capacidade de cargas na última década do século, conforme expresso no Gráfico 8, as informações da sociedade de estatística inglesa nos trouxeram alguns dados relativamente impressionantes.

O número total de embarcações, considerando as 43 empresas inventariadas por nossa fonte, salta de 1.449, no ano de 1891, para 2.025, no ano 1901. A capacidade total trafegada por essas embarcações é de 3.457.273 toneladas, em 1891, e de 7.059.717 toneladas, em 1901. 
Gráfico 7 - Capacidade de carga da frota transoceânica a vapor por nacionalidade, 1838-1881

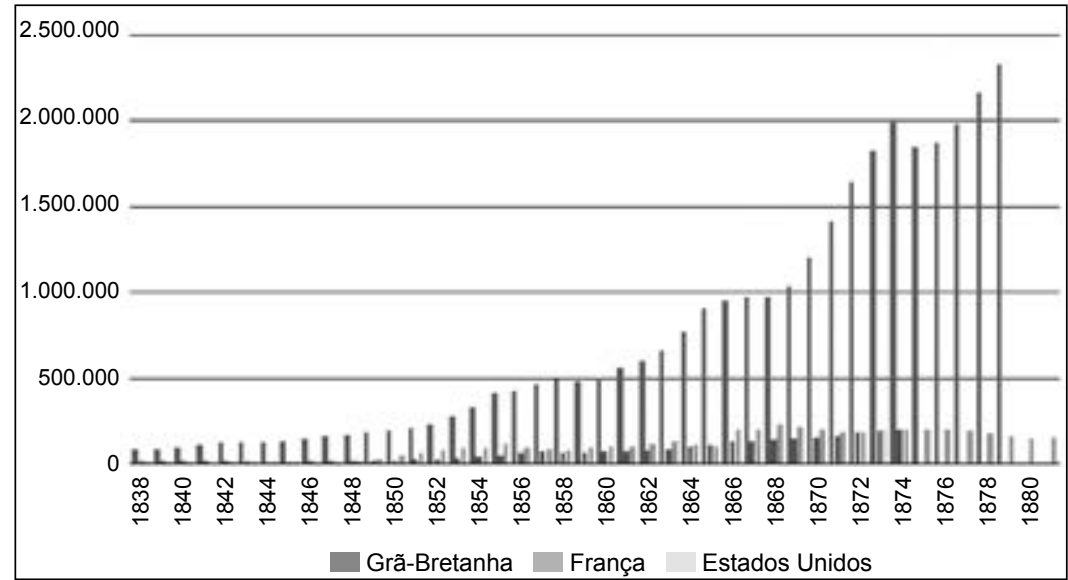

Fonte: Preble (1881, p. 193).

Mesmo considerando apenas a última década do século, esses números demonstram o substancioso acréscimo na frota transoceânica a vapor em 39,7\%; mas o que mais nos surpreende é o espantoso salto da capacidade de carga dessas embarcações, acrescida em 104\%!

A disparidade dessas duas taxas de crescimento apontam para algo que já frisamos: durante todo o século XIX, existe uma tendência inequívoca para o agigantamento das embarcações, cada unidade de vapores marítimos deveria ter mais espaço de carga, transportar mais passageiros, além de ter maior autonomia. Esse processo é coerente com a mudança do "cardápio de serviços" oferecido pelas companhias. As maiores oferecem uma amplitude realmente impressionante de modalidades de transportes, mas, a partir da década de 1870, as correspondências passam a ocupar papel secundário nas atividades das companhias de navegação; no último quartel de século, os fretes, as entregas em linhas regulares e o serviço de passageiros passaram a ocupar a maior parte de suas embarcações, a compor o mais substantivo de seus lucros e a representar a fração majoritária de suas atividades. 
Gráfico 8 - Capacidade de carga e frotas de embarcações a vapor, 1891-1901

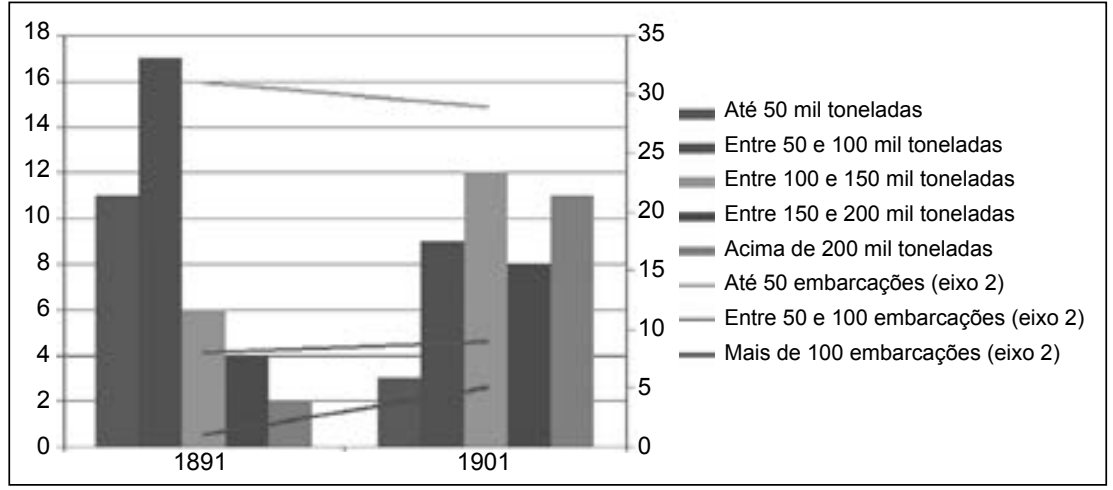

Fonte: Journal of the Royal Statistical Society (1901).

Gráfico 9 - Maiores frotas de embarcações a vapor, 1891

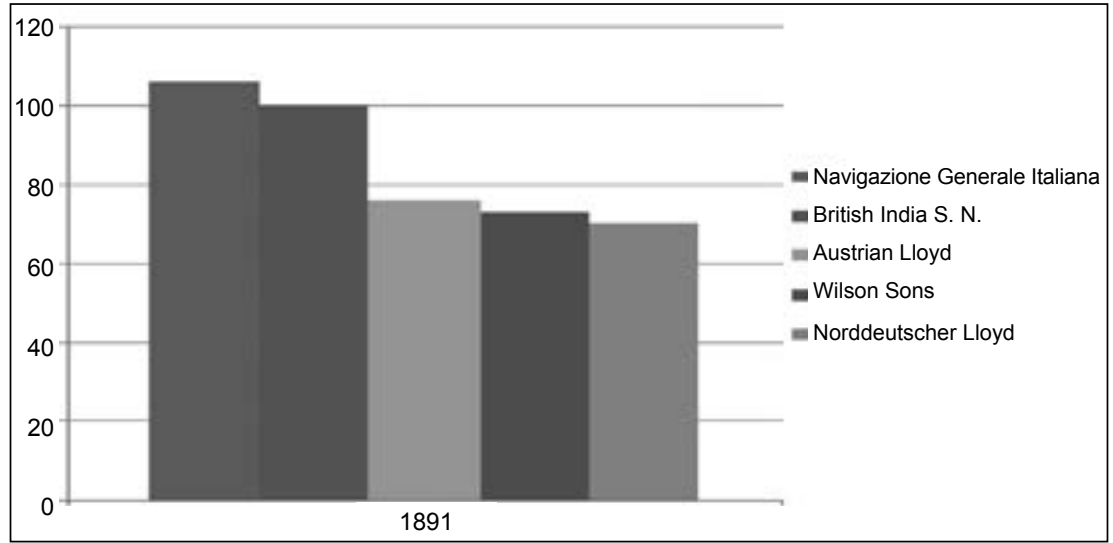

Fonte: Journal of the RoyalStatistical Society (1901).

Certamente que surpreende o número de embarcações da Navigazione Generale Italiana. O porte médio delas, entretanto, deveria ser relativamente menor que a maioria dos paquetes ingleses e alemães. Fundada em 1881, a companhia italiana fazia serviço de frete para os Estados Unidos e o Canadá, mas sua especialidade estava na navegação mediterrânica e no mar Negro. Mais tarde, a NGI ficou conhecida como principal transportadora da imigração italiana para o Novo Mundo (Kennedy, 1903). 
Entretanto, parece-nos previsível os números registrados pelas companhias britânicas, maior potência naval e mercante do mundo. Fundada em 1856, a Britsh Indian Steam Navegation fazia intensa navegação de cabotagem nos portos da colônia, baseada em Calcutá; também fazia o serviço de longo curso para Londres e Middlesbrough (Preble, 1881). Convém aqui reproduzir Ellen Wood acerca do imperialismo inglês na relação com sua principal colônia:

À medida que aumentava a atração do império como fonte de renda, mais o imperialismo territorial crescia. Quando o império na Índia se tornou uma forma mais - e não menos - tradicional de imperialismo não capitalista, baseada na extração extraeconômica de impostos por meio da tributação, ele se tornou também cada vez mais um despotismo militar. (Wood, 2014, p. 189)

Diferente de Hobsbawm, a autora não enxerga o Império inglês como tipicamente capitalista, pela relação de espoliação tributária e coerção militar que desenvolveu na Índia. Discordamos em partes, pois, se é verdade que as relações sociais de produção capitalistas na Índia encontraram no imperialismo inglês um importante obstáculo, é também verdade que, especialmente em países recém-formados da América Latina, os instrumentos exclusivamente econômicos do imperialismo inglês, combinados com pressões diplomáticas e geopolíticas, fizeram com que as tensões capitalistas penetrassem mais fundo em outras formações econômico-sociais. O próprio desenvolvimento da navegação a vapor, na costa indiana, é indício de que esse processo de tensionamento, na principal colônia inglesa, não estava completamente nulo.

Não é de espantar que fossem francesas duas das companhias com as maiores capacidades de carga na fonte compulsada. Em 1835, o governo francês criou uma linha de navegação a vapor oficial entre Marselha e a região do Levante, no Mediterrâneo Oriental. A Compagnie des Messageries Maritimes continuou pública até 1851, quando foi transferida à gerência da Messageries Nationales, uma empresa privada, tornando-se a Compagnie de Messageries Impériales. Em 1857, a companhia já possuía 57 navios e navegava até Constantinopla e a Argélia, assim como a companhia italiana, sua especialidade era o mar Mediterrâneo e Negro, interligando metrópole e colônias (Rainey, 1858). 
Entretanto, já na década de 1860, envolveu-se no tráfego transatlântico fazendo a linha mensal entre Bordeaux e o Rio de Janeiro, além de trafegar pelo canal de Suez desde sua inauguração.

O Lloyd de Bremen é, possivelmente, o melhor exemplo de monopólio dentre as companhias citadas. A Norddeutscher Lloyd foi fundada em 1857 pela fusão de quatro empresas menores, começou a navegar entre Bremen e Londres com seis vapores de 500 toneladas. As viagens transatlânticas para Nova York começaram em junho de 1858; por volta de 1866, a sua linha para o maior porto das Américas passou a ser semanal (Preble, 1881).

Gráfico 10 - Capacidade total de carga das maiores companhias de navegação a vapor, 1891 (em toneladas)

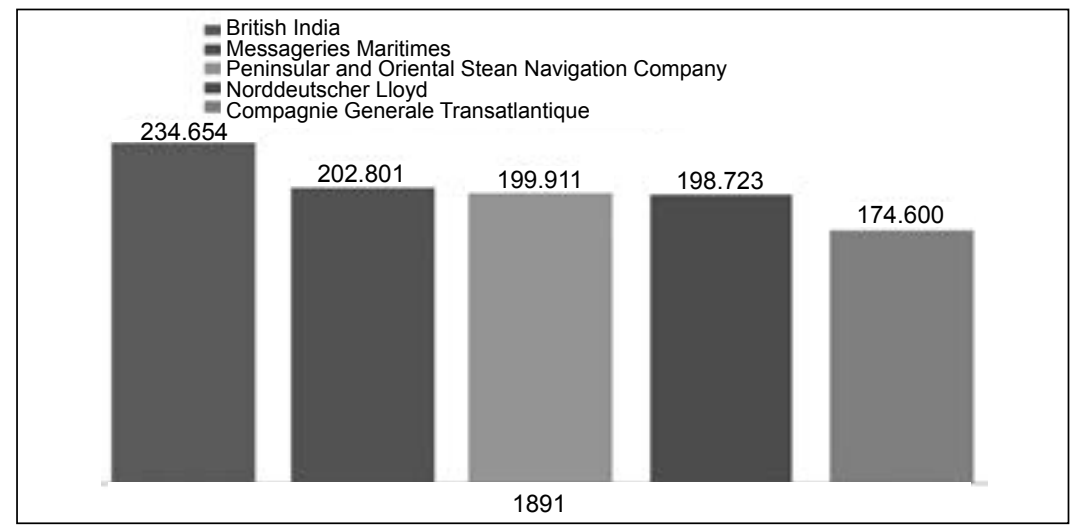

Fonte: Journal of the Royal Statistical Society (1901).

Em 1874, a viagem entre Bremen e Nova York durava, em média, 11 dias. As viagens de Bremen para o Brasil e o rio da Prata começaram em 1876. Uma das razões para o sucesso dos Lloyds alemães foi a aposta na velocidade de suas viagens:

Among the causes of its growth there is only one that can be cited with full confidence; an improvement in the technology of boat-building and navigation such as to make extensive sea voyages practicable in sufficient force and with sufficiently reduced risk of accidents by sea. (Veblen, 1915, p. 120) 
Gráfico 11 - Maiores frotas de embarcações a vapor, 1901

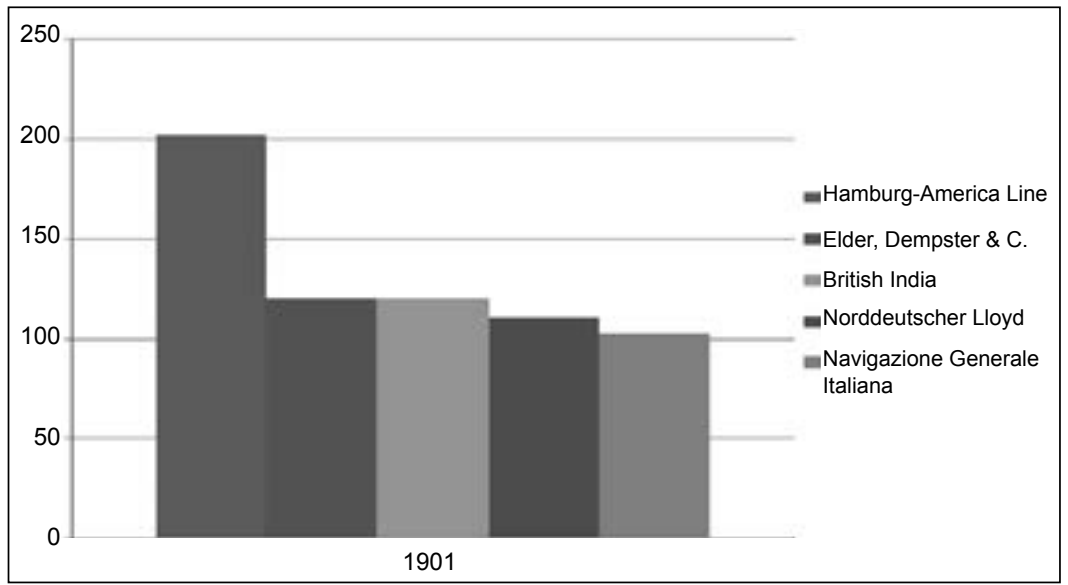

Fonte: Journal of the Royal Statistical Society (1901).

Gráfico 12 - Capacidade total de carga das maiores companhias de navegação a vapor, 1901 (em toneladas)

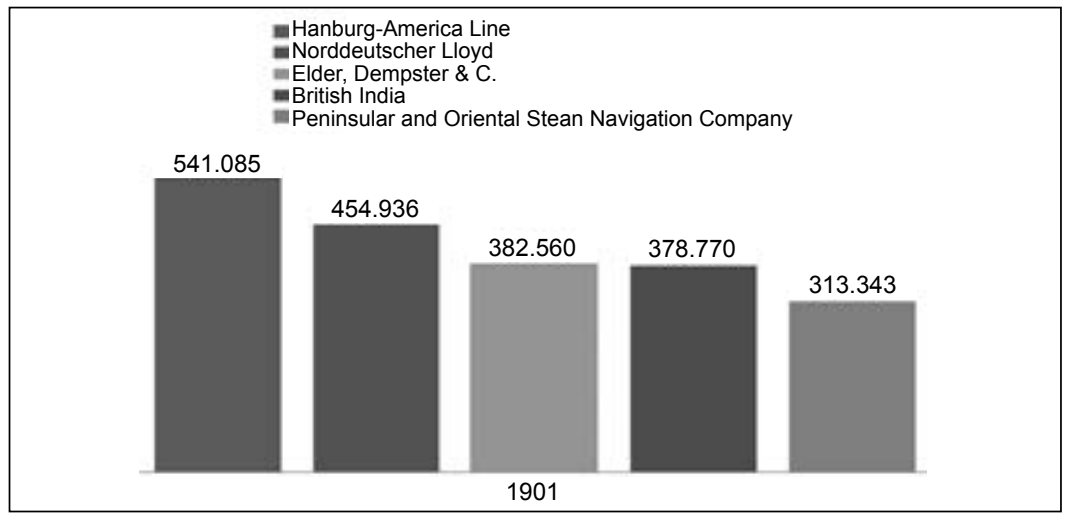

Fonte: Journal of the Royal Statistical Society (1901).

Fundada em 1836, as grandes embarcações da Peninsular \& Oriental Steam Navigation Company navegaram entre Londres, Espanha e Portugal inicialmente. O grande porte das embarcações da P \& O se dava por sua peculiaridade de ser a companhia que arrematou os principais contratos do correio imperial inglês para o Mediterrâneo e o Oriente. A carga era certa e volumosa, suas embarcações eram verdadeiros co- 
lossos para a época. A partir de 1840, operou um serviço de correio regular, inicialmente contratado para as entregas em Alexandria, depois até o Cairo pelo rio Nilo e canal de Suez. O seu serviço de correio prosperou e chegou aos portos de Bombaim, Ceilão, Calcutá, Singapura, Hong Kong e Shanghai. Em 1852, o serviço de correio foi estendido mais ainda para a Austrália (Rainey, 1858).

Fundada em 1847, citada por Lenin, a Hamburg-American Packet Company foi a maior companhia de navegação a vapor do século XIX. Navegou de Hamburgo para Nova York via Southampton ainda à vela, quando a viagem demorava cerca de 40 dias. Na década de 1860, transformou toda sua frota em vapores e foi a primeira a generalizar o uso do casco de aço, e suas embarcações eram mais resistentes, autônomas, velozes, espaçosas e confortáveis; nas décadas de 1870 e 1880, adotou um programa agressivo de incorporação de várias pequenas e médias companhias: em 1875, incorporou a do Sr. Adler e, em 1886, se fundiu com a linha Carr-Union. Entre 1888 e 1890, tomou a feição final de maior truste da navegação marítima mundial, assumiu as companhias Hamburg South American (passando a navegar para o Brasil e rio da Prata), German East Africa Line (passando a navegar até a África do Sul) e a companhia que fazia a linha entre as cidades hanseáticas (Kennedy, 1903). O Lloyd de Hamburgo foi a primeira companhia de navegação a vapor que ultrapassou a marca de meio milhão de toneladas transportadas entre continentes pela via marítima.

Como podemos constatar, os colossos alemães e ingleses concentravam boa parte da capacidade de carga total que trafegava pela força dos vapores nos oceanos, especialmente no Atlântico. A disputa entre potências imperialistas se dava de forma muito clara na navegação transoceânica. Além de extremamente necessária para efetivação dos capitais e mercadorias que transbordavam do centro para a periferia no sistema capitalista em mundialização, era ela mesma uma grande oportunidade de investimento dos capitais cada vez mais concentrados em monopólios na nova fase do capitalismo.

\section{Considerações finais}

A Segunda Revolução Industrial mudou o padrão de deslocamento 
das grandes embarcações transoceânicas. Os avanços tecnológicos como a força a vapor, a hélice submersa, o casco de ferro e o de aço, ou o guindaste de bordo só puderam ser viabilizados com a potência das forças imperialistas. O capital monopolista atuou de forma marcante nos mares e utilizou dos transportes marítimos como veículo de sua dominação, especialmente na forma de exportação dos capitais ociosos no núcleo capitalista.

De toda forma, parece-nos que as embarcações transoceânicas a vapor completaram, na navegação marítima, o ciclo da industrialização necessária para o pleno desenvolvimento das forças produtivas nos transportes em longa distância; entretanto, os portos do mundo inteiro não acompanharam esse desenvolvimento e rapidamente suas infraestruturas se tornaram defasadas diante do novo e impressionante porte das embarcações, além do movimento de mercadorias e pessoas.

Desde a embarcação mista criada por Robert Fulton, passando pelas pioneiras empresas de correspondência contratadas pelos governos, até os gigantescos Lloyds monopolistas, a história dos vapores marítimos foi condicionada por diversas conjunturas e sua generalização foi impulsionada pela modificação estrutural no sistema capitalista, ocorrida no último quarto do século XIX. Definitivamente, podemos dizer, o protagonismo dos transoceânicos a vapor nos transportes de longa distância surge com o estabelecimento do Imperialismo Capitalista.

\section{Referências bibliográficas e fontes}

BEAUD, Michel. História do capitalismo de 1500 aos nossos dias. São Paulo: Brasiliense, 1989.

BOWEN, Frank. A century of Atlantic travel: 1830-1930. Boston: Little, Brown \& C., 1930. BROWN, Michael. A economia política do imperialismo. Rio de Janeiro: Zahar, 1978.

BUKHARIN, Nikolai. A economia mundial e o imperialismo. São Paulo: Abril Cultural, 1984.

CARUSO, Laura. Embarcados: los trabajadores marítimos y la vida a bordo. Sindicato, empresas y Estado em el Puerto de Buenos Aires (1889-1921). Buenos Aires: Imago Mundi, 2016.

CIPOLLA, Carlo. Historia económica de la población mundial. Barcelona: Crítica, 2013.

CUNNINGHAM, William. The growth of English industry and commerce in modern times. Cambridge: Cambridge University Press, 1917. 
DOBB, Maurice. A evolução do capitalismo. São Paulo: Nova Cultural, 1983 (coleção Os Economistas).

DOLLAR, Robert. One hundred thirty years of steam navigation. San Francisco: Robert Dollar Company, 1931.

DUGAN, Sally. Menofiron: Brunel, Stephenson and the inventions that shaped the world. London: Macmillan, 2003.

DUSSEL, Enrique. Carlos Marx - cuaderno tecnológico-histórico. Ciudad de México: Universidad Autonoma de Puebla, 1984.

ENGELS, Frederich. A situação da classe operária inglesa. São Paulo: Boitempo, 2008.

ENGELS, Friedrich; MARX, Karl. Manifesto comunista. São Paulo: Boitempo, 2013.

FOSTER, William. Fortunes made in business: a series of original sketches, biographical and anecdotic, from the recent history of industry and commerce. London: Sampson Low, Marston, Searle \& Rivington, 1884.

FRY, Henry. Atlantic steam navigation. Bristol: s.ed., 1883.

FRY, Henry. The history of North Atlantic steam navigation, with some account of early ships and shipowners. London: Sampson Low, Marston, Searle \& Rivington, 1896.

HILFERDING, Rudolf. O capital financeiro. São Paulo: Nova Cultural, 1985.

HOBSBAWM, Eric. Industria e Imperio. Barcelona: Ariel, 1982.

HOBSBAWM, Eric. Era dos Impérios (1875-1914). Rio de Janeiro: Paz e Terra. 1988.

HOBSON, John. A evolução do capitalismo moderno: um estudo da produção mecanizada. São Paulo: Abril Cultural, 1983.

IGLÉSIAS, Francisco. A Revolução Industrial. São Paulo: Brasiliense, 1981.

JOURNAL of the Royal Statistical Society. London, Blackwell Publishing, set. 1901.

KEMP,Tom. A Revolução Industrial na Europa do século XIX. Lisboa: Edições 70, 1987.

KENNEDY, John. The history of steam navigation. London: Charles Birchall, 1903.

LANDES, David S. Prometeu desacorrentado. Rio de Janeiro: Nova Fronteira, 1994.

LENIN,Vladimir. O imperialismo: fase superior do capitalismo. Lisboa: Avante, 2013.

MANTUANO, Thiago Vinícius. O trapiche e suas fronteiras: a operação portuária pré-capitalista no Rio de Janeiro do século XIX. Rio de Janeiro: Autografia, 2015.

MARSHALL, Alfred. Princípios de economia política. São Paulo: Nova Cultural, 1996 (coleção Os Economistas).

MARX, Karl. O capital. São Paulo: Nova Cultural, 1988.

MASON, Stephen. Historia de la ciencia. Madrid:Alianza, 1993, 4 v.

MORRISON, John Harrison. History of American steam navigation. New York: Sametz, 1908.

OWEN, Douglas. Ports and docks: their history, working, and national importance. London: Methuen, 1904.

POLANYI, Karl. A grande transformação: as origens da nossa época. Rio de Janeiro: Campus, 2000.

PINTO FERREIRA, Carlos Augusto. Manual elementar e prático sobre máquinas de vapor marítimas antigas e modernas: compreendendo as de dupla, tríplice e quádrupla. Lisboa: Impressa Nacional, 1888. 
PREBLE, George. Notes for a history of steam navigation. Philadelphia: J. B. Lippincott \& Co., 1881.

RAINEY,Thomas. Ocean steam navigation and the ocean post. New York: Appleton, 1858.

RIOUX, Jean-Pierre. A Revolução Industrial (1780-1880). São Paulo: Livraria Pioneira, 1975.

RUSSELL SMITH, John. Ocean freight rates and their control by line carriers. Journal of Political Economy. The University of Chicago Press, v. 14, n. 9, p. 525-541, Nov. 1906.

SUÁREZ BOSA, Miguel (org.). Atlantic ports and the first globalisation (1850-1930). Hampshire: Cambridge Imperial - Palgrave MacMillan, 2013.

SWEEZY, Paul; BARAN, Paul. O capital monopolista: ensaio sobre a ordem econômica e social americana. Rio de Janeiro: Zahar, 1966.

VEBLEN,Thorstein. Imperial Germany and the Industrial Revolution. NewYork: Macmillan, 1915.

WOOD, Ellen. O império do capital. São Paulo: Boitempo, 2014.

WOODCROFT, Bennet. A sketch of the origin and progress of steam navigation from authentic documents. London:Taylor, Walton and Maberly, 1848. 